\title{
Cognitive and motivational effectiveness of an interdisciplinary case method experiment at the University of Stuttgart
}

\author{
Karl-Friedrich Ackermann \\ University of Stuttgart, Stuttgart
}

An experiment on the value of the case study method was carried out at the University of Stuttgart in the Federal Republic of Germany, to ascertain whether the case study method was superior to the traditional teaching methods, especially with a view to increasing requests that university education should be more practice-related. The main deficiencies of traditional business teaching methods are indicated, as well as the perceived satisfaction and importance of the basic needs as seen by a number of students. In the experiment five business administration and five engineering students were used, while a large business firm and some of its sub-contractors gave feedback from the business world itself. Towards the end of the experiment the students' opinions on the value of the case method compared with traditional teaching methods was obtained by means of anonymous questionnaires. They rated the case study method as substantially superior with regard to increasing knowledge, and to improving both technical and inter-personal competence. The same conclusions were drawn as to the affective area of learning, including increased and better satisfied intrinsic motivation to achieve, and to cooperate in small task groups.

S. Afr. J. Bus. Mgmt. 1982, 13: $126-135$

'n Eksperiment oor die waarde van die gevallestudiemetode is by die Universiteit van Stuttgart in die Bondsrepubliek Duitsland uitgevoer, om vas te stel of die gevallestudiemetode meer effektief as die tradisionele opleidingsmetodes is, veral met die oog op voortdurende versoeke dat univesiteitsopleiding meer praktykgeoriènteerd moet wees. Die hoof tekortkominge van tradisionele opleidingsmetodes word aangedui, asook waargenome bevrediging en belangrikheid van die basiese behoeftes soos deur 'n aantal studente ondervind. In die eksperiment is vyf studente in bedryfsadministrasie en vyf ingenieurstudente gebruik, terwyl 'n groot onderneming en 'n aantal van sy sub. kontrakteurs terugvoering direk van die sakewereld verskaf het. Teen die einde van die eksperiment is die studente opinie aangaande die waarde van die gevallestudiemetode teenoor tradisionele opleidingsmetodes verkry deur middel van anonieme vraelyste. Die studente beskou die gevallestudiemetode as aansienlik beter ten opsigte van die vermeerdering van kennis, asook die verbetering van tegniese en interpersoonlike vaardighede. Ten opsigte van die affektiewe leerarea, insluitende beter en meer bevredigde intrinsieke motivering om te presteer en binne 'n groep saam te werk, is dieselfde gevolgtrekking gemaak.

S.-Afr. Tydskr. Bedryfsl. 1982, 13: $126-135$

\section{Introduction}

If we look back at the case method experiment ${ }^{1,2,3}$ that we have been engaged in for nearly two years, our feelings are somewhat divided. There is, first of all, a very positive feeling, which has probably grown in strength as time passed. This is owing to the content of the work which had to be done and to the rather unusual way in which it was performed in cooperating task groups of business students and engineering students who closely interacted with top managers of various companies.

A positive feeling relates, finally, to the results of the experiment in terms of cognitive and motivational effectiveness reached in spite of, or maybe because of, our initially very restricted expectations of success. The reason for the latter becomes clear if one realizes the conditions for participation; contrary to our own prejudices and to well-minded advice from colleagues working in the same field, we consciously refused to offer any additional incentives for joining the case method experiment other than hard, interesting work and the chance to practise high degrees of self-direction and self-control in largely autonomous task groups. No student was obliged to take part, and no student could hope to get a performance record or any other immediate advantage for his or her final exam. We only told them: 'There is a project in a heavy machinery company: "Planning and building a power plant" with a large number of economic and engineering problems. Carefully study the documents that we have prepared for you, then come and join the task groups.' We are still surprised that under these circumstances the whole experiment did not have to be dropped sooner or later simply because of a lack of participants ready and qualified enough to meet the high project requirements.

In this case we relied on higher-order needs in terms of Maslow, ${ }^{4}$ or on 'motivators' in terms of Herzberg.' McGregor would have said that we used a 'Theory Yapproach' instead of a traditional 'Theory $\mathrm{X}$-approach'. ${ }^{6}$ From his point of view it is of course far more surprising that we tend to rely on the superiority of Theory $\mathrm{X}$, consciously or not, when university study programmes are designed and even when progressive teaching methods such as the case method are applied. Though McGregor's Theory $\mathrm{Y}$ vs Theory X-discussion was directed at business organizations, both approaches can be immediately transferred to the field of university education. It is shown 
that the existing university education system uses, to a large extent, Theory $\mathrm{X}$-oriented means of motivating students to participate and perform in lectures, seminars and courses. This is done by stressing their compulsory character, their special importance for forthcoming exams and the necessity of accomplishing certain exam prerequisites and the like. Sometimes case method applications are offered in the same traditional way, because instructors fear that students will not take part otherwise.

We have already indicated that the experiment also calls forth negative feelings. They are to be reported at this point before we follow a well-known trend in human nature of sticking to the favourable issues while suppressing the unfavourable ones. There are four main reasons which gave rise to such feelings during the experiment:

- Time options for group meetings were very restricted because the experiment was offered as a supplement to the ongoing standard study programme which required, then and today, most of the working time of the students.

- Progress in group work depended, to a large extent, on the information flow between the cooperating student groups as well as between those groups and the companies. In spite of the intensive efforts of all participants, information needed was not always available on time or - even worse - could not be provided at all in the desired quantity and quality. Then, group work in regard to a certain partial project had to be temporarily interrupted and switched to other partial projects of the case method programme.

- Cooperation and coordination of the business and engineering groups in the experiment proved to be far more difficult and time consuming than we had expected and never reached the effectiveness we desired.

- Some of the objectives defined for the experiment were partially conflicting. The objectives will be discussed later in the article.

- Although these problems had been anticipated to some extent, we had clearly underestimated the high degree of stress which continued to occur. We should have concerned ourselves with a reasonable compromise between, say, striving for more technical competence and for more interpersonal competence of the students in each group meeting. But we often suffered from the temptation to give up our elaborate 'moderator concept' designed to develop interpersonal competence and to return to routinized teacher-oriented concepts traditionally used to enforce improvements in technical competence only. Whoever, as an instructor, has ever tried to shift more activity, more selfdirection and self-control to the students, while checking his own impatience, knows what we mean.

It could be argued that the difficulties observed in case discussion meetings, when the scope for project-related activities of the student participants was considerably enlarged as compared with standard seminars and courses, indicate wrong behavioural premises upon which the case method experiment had been built. From this criticism it is only a minor step to a thorough rejection of the underlying Theory $Y$-approach as a nice but unrealistic utopia. We shall not follow this line of reasoning, but shall consider difficulties of the kind mentioned as behavioural defi- ciencies which could be reduced by means of the case approach.

On the whole, from the instructors' point of view, these negative experiences do not diminish the prevailing positive impression of the case method experiment. We tend to an even more favourable judgement now than we did earlier. Time restrictions, incomplete information, interdepartmental problems and conflicting objectives all are phenomena wide-spread in business firms. Why not interpret their occurrence as a proof that the experiment was particularly successful in modelling reality, possibly to a larger extent than we had wanted or expected? The more we think back about this, the more reasonable this argument appears to be. In the following report on the experiment we shall discuss in more detail:

- the learning objectives

- the experimental design and

- the results in terms of various effectiveness criteria as perceived by the students.

For the better understanding of the experiment, however, its theoretical and empirical background will be explained first in the next two sections.

\section{Critical issues of the existing university education system}

The case method experiment was strongly stimulated by the ongoing 'study reform discussion' which has drawn special attention to the problem of how to improve the practice-relatedness of university education programmes in the field of economics and business administration. ${ }^{7,8}$ In our opinion, there are four main deficiencies in today's university education of future business executives which should be reduced or even eliminated by means of properly designed applications of the case method.

\section{Lack of intrinsic motivation}

There is, first of all, a striking deficiency in intrinsic motivation when students' behaviour is observed. According to instructors study is seldom undertaken because of genuine intrinsic interest in the problems offered in the different lectures and courses, or because of a deep-rooted belief in the immediate usefulness of such knowledge for the desired management jobs, but mainly for nothing else than the perceived need to meet the requirements of the current study programme and to pass the next exams. It is not our intention to blame students for this kind of behaviour since it results from the existing university education system and its traditional instruments like compulsory study programmes, restrictions of maximum study time allowed, teacher-centred lectures and courses and, finally, a tight network of performance controls. All those instruments look very similar to McGregor's original description of a Theory $\mathrm{X}$-approach which tends to suppress rather than to evoke and develop intrinsic motivation. In this way one of the most powerful sources of learning, motivation, remains unused by the existing university education system. Even more important, as most theorists and management experts will agree, executives in business organizations should get intrinsic motivation from the work itself and should show a dominant Theory Y-type behaviour as opposed to a Theory $\mathrm{X}$-type behaviour. If 
we follow this view which is largely in accordance with recent empirical findings of motivation research in industry, then a severe gap in the motivational development of business students becomes obvious.

\section{Preference for structured courses}

Secondly, many students prefer well-organized, wellstructured lectures and teacher-centred courses which reduce true problem-solving activities by themselves to a minimum. Again, the discrepancy between the learning behaviour strengthened by the existing university education system, and the job requirements of the employment system is unacceptable.

\section{Lack of group problem solving opportunity}

A third critical issue is related to the fact that the existing university education system provides very limited opportunity for students to practice group problem-solving, that ability being a highly appreciated qualification in modern management. Much emphasis is put on knowledge and technical competence, while interpersonal competence is largely ignored.

\section{Lack of feedback from business}

Finally, students are not used to having real feedback to their work from business firms. Their situation is rather similar to that of participants in a dry swimming course who may always see the water but are not allowed to jump into it.

These deficiencies were the principal starting points for the design of the case method experiment. Before we take a closer look at the objectives defined for the experiment, some empirical research findings about the present state of students' motivation will be considered.

\section{Perceived satisfaction and Importance of basic needs as seen by students}

Three different groups of students at the Business Institute of the University of Stuttgart and, for comparison, a group of graduates in entry-level positions, were asked for their judgement of perceived satisfaction and the importance of basic needs in terms of their present situation by means of a slightly modified Porter Need Satisfaction Questionnaire (PNSQ). The PNSQ provides 13 items representing 5 Maslow-type areas of psychological needs: security, social, esteem, autonomy, and self-actualization. Satisfaction attached to each item is measured in terms of differences between two separate ratings on a 7-point-scale ranging from 1 (min.) to 7 (max.), one rating according to the question: 'How much (of a certain item) should there be?' the other according to the question: 'How much (of this item) is there now?' It is assumed that, as the positive difference between 'should be' and 'is', approaches its maximum possible value of +6 , the higher the degree of perceived need dissatisfaction will be, and vice versa. The importance attached to each item is measured by the same 7-point-rating scale asking 'How important is this (item) to me?' The research findings are listed in the Tables. (The empirical motivation study was done after the case method experiment had been completed. However, the findings of the study confirm, to a large extent, the basic premises that guided our experiment from the beginning.)
Table 1 clearly shows that undergraduates experience the highest deficiencies in need fulfilment in the area of autonomy needs and self-actualization needs compared with other Maslow need categories investigated. The degree of the deficiencies obviously increases when students progress from the two-year period of basic courses (Grundstudium) to the two-year period of advanced courses (Hauptstudium), and then decreases very strongly after they have received their degree and entered into entry-level positions in business firms or elsewhere.

The findings seem to reflect the inability of the existing university education system and its traditional teaching arrangements to satisfy higher-order needs in terms of Maslow's need hierarchy theory. Those findings fit well with the 4-point-catalogue of critical issues discussed in the previous section, particularly if the first two of them are considered. The facts that instructors observed a lack of intrinsic motivation and of active learning behaviour, and that at the same time students suffered from deficiencies in the fulfilment of higher-order needs, highlight the demand for new teaching methods such as the case method.

Under properly designed conditions each student can and will learn to satisfy his or her own self-actualization and autonomy needs by means of active participation in problem-solving. To realize such conditions was exactly what we wanted to do when we decided to design a Theory Y-oriented case method experiment. If it is true that higherorder needs are 'growth-needs', as Maslow once pointed out, growing in strength as they become more and more satisfied, then the experiment should also contribute to the development of those needs so largely neglected by the existing university education system.

The present state of student motivation remains incompletely described if the extent of deficiencies in need fulfilment are considered alone. Our arguments that the case method experiment should improve the satisfaction of autonomy and self-actualization needs would be even more persuasive if students tended to attach high importance to those need categories. The research findings on this question are shown in Table 2.

According to Table 2 the higher-order needs of the undergraduates being satisfied least are rated by the same respondents as highly important to them. If one looks at the rank orders first, self-actualization is always number one in the three separate subgroups of undergraduates and in the comparative group of graduates as well. Autonomy with a rank of four in the first two study years seems to be far less important. By the stage of advanced courses selected for the case method experiment, however, this need category reaches a rank of three - later even a rank of two - with nearly as high a mean importance score as selfactualization. For the same reasons, although decreasing in rank order, social needs should not be overlooked as an important need category of undergraduates in the selected area.

\section{Objectives and design of the case method experiment}

Objectives of the case method experiment

Asking what the participants of the experiment should learn in terms of final behaviour and what areas and types of learning would be involved lead to a multi-dimensional 
Table 1 Mean deficiencies in need fulfilment $\bar{D}$ within different subgroups of undergraduates and graduates of the University of Stuttgart in the years 1979 and 1980

\begin{tabular}{|c|c|c|c|c|c|c|c|c|}
\hline \multirow[b]{5}{*}{ Need category } & \multicolumn{8}{|c|}{ Mean deficiencies in need fulfilment $\bar{D}$} \\
\hline & \multicolumn{6}{|c|}{ Undergraduates } & \multirow{3}{*}{\multicolumn{2}{|c|}{$\begin{array}{c}\text { Graduates } \\
\text { (Diplom- } \\
\text { kaufleute) } \\
\text { in entry- } \\
\text { level } \\
\text { positions } \\
N=28\end{array}$}} \\
\hline & \multirow{2}{*}{\multicolumn{2}{|c|}{$\begin{array}{l}\text { in basic } \\
\text { courses } \\
\text { (Grund- } \\
\text { studium) } \\
N=75\end{array}$}} & \multicolumn{4}{|c|}{$\begin{array}{c}\text { in advanced } \\
\text { courses } \\
\text { (Hauptstudium) }\end{array}$} & & \\
\hline & & & $N$ & $=19$ & $N$ & $=47$ & & \\
\hline & $\overline{\mathbf{D}}$ & Rank & $\overline{\mathbf{D}}$ & Rank & $\overline{\mathbf{D}}$ & Rank & $\overline{\mathbf{D}}$ & Rank \\
\hline $\begin{array}{l}\text { I. Physiological } \\
\text { needs }\end{array}$ & . & . & . & . & . & . & $\cdot$ & . \\
\hline 1I. Safety needs & 1,1 & 4 & 1,2 & 4 & 2,1 & 3 & 0,1 & 5 \\
\hline III. Social needs & 1,4 & 3 & 1,5 & 3 & 1,8 & 4 & 0,3 & 4 \\
\hline IV. Esteem needs & 0,3 & 5 & 0,2 & 5 & 0,5 & 5 & 0,4 & 3 \\
\hline V. Autonomy needs & 2,5 & 1 & 3,1 & 1 & 3,2 & 1 & 1,0 & 2 \\
\hline $\begin{array}{l}\text { VI. Self-actualization } \\
\text { needs }\end{array}$ & 2,0 & 2 & 2,1 & 2 & 2,8 & 2 & 1,8 & 1 \\
\hline
\end{tabular}

Table 2 Mean importance of each need category within different subgroups of undergraduates and graduates of the University of Stuttgart in the years 1979 and 1980

\begin{tabular}{|c|c|c|c|c|c|c|c|c|}
\hline \multirow[b]{5}{*}{ Need category } & \multicolumn{8}{|c|}{ Mean importance $\bar{W}$ of each need category } \\
\hline & \multicolumn{6}{|c|}{ Undergraduates } & \multirow{3}{*}{\multicolumn{2}{|c|}{$\begin{array}{c}\text { Graduates } \\
\text { (Diplom- } \\
\text { kaufleute) } \\
\text { in entry- } \\
\text { level } \\
\text { positions } \\
N=28\end{array}$}} \\
\hline & \multirow{2}{*}{\multicolumn{2}{|c|}{$\begin{array}{l}\text { in basic } \\
\text { courses } \\
\text { (Grund- } \\
\text { studium) } \\
N=75\end{array}$}} & \multicolumn{4}{|c|}{$\begin{array}{c}\text { in advanced } \\
\text { courses } \\
\text { (Hauptstudium) }\end{array}$} & & \\
\hline & & & \multicolumn{2}{|c|}{$N=19$} & \multicolumn{2}{|c|}{$N=47$} & & \\
\hline & $\overline{\mathbf{W}}$ & Rank & $\overline{\mathbf{W}}$ & Rank & $\overline{\mathbf{W}}$ & Rank & $\overline{\mathbf{W}}$ & Rank \\
\hline $\begin{array}{l}\text { I. Physiological } \\
\text { needs }\end{array}$ & . & • & . & . & . & . & . & \\
\hline II. Safety needs & 5,3 & 3 & 4,6 & 4 & 5,4 & 2 & 5,2 & 3 \\
\hline III. Social needs & 5,5 & 2 & 4,8 & 3 & 5,1 & 4 & 4,2 & 5 \\
\hline IV. Esteem needs & 3,8 & 5 & 3,6 & 5 & 4,1 & 5 & 4,7 & 4 \\
\hline v. Autonomy needs & 5,1 & 4 & 4,9 & 2 & 5,3 & 3 & 5,3 & 2 \\
\hline $\begin{array}{l}\text { VI. Self-actualization } \\
\text { needs }\end{array}$ & 5,8 & 1 & 5,5 & 1 & 5,5 & 1 & 6,0 & 1 \\
\hline
\end{tabular}

system of objectives as shown in Table 3.

In the first part of Table 3 , objectives are specified in terms of general behaviour categories which should be learned by means of the case method. They relate, in short, to desired motivational dispositions of the participants (1), and to all stages of problem-solving and project management $(2-8)$, namely: problem-finding, scheduling, executing, evaluating, controlling, integrating, and reporting. Some of them look very simple indeed and unworthy of mention in the table. There is, for example, the objective 'to identify and define problems in real life incidents'. Traditional lectures and seminars, dealing with welldefined, clear-cut problems and theories in general, offer

\section{Table 3 Objectives of the case method experiment}

Participants should learn:

1. to experience more and stronger motivation related to problem-solving and team-work

2. to identify and define relevant sub-problems in real life incidents (problem-finding)

3. to schedule a well-structured programme for multi-project problemsolving, including sub-programmes which determine in some detail the succession and available scope of time for each single project (scheduling)

4. to execute the self-determined programme and its sub-programmes in largely autonomous task groups under changing management of self-elected student leaders. Main activities: Searching for information, elaborating alternative courses of action (executing)

5. to evaluate courses of action for each single project in the light of present theories, taking into consideration the specific conditions of the cooperating company (evaluating)

6. to control the results of the problem-solving processes together with experts of the cooperating company with regard to applicability, effectiveness, etc. (controlling)

7. to integrate the selected types of problems in the larger context of the cooperating company and, finally, of the whole industry (integrating)

8. to summarize the main results in a final group report (reporting)

In order to approach these behavioural objectives, the following prerequisites or types of learning should be accomplished

\begin{tabular}{|c|c|c|c|}
\hline \multirow{3}{*}{ 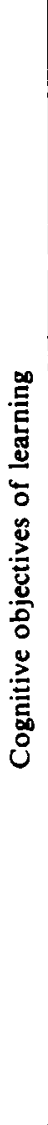 } & \multicolumn{2}{|c|}{ 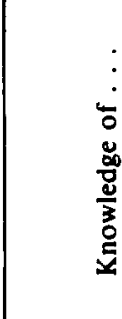 } & $\begin{array}{l}1 \text { Concepts and facts } \\
2 \text { Routines and heuristics involved } \\
3 \text { Classification schemes for structuring incidents ac- } \\
\text { cording to general types of problems } \\
4 \text { Criteria for evaluating methods, techniques and } \\
\text { courses of action } \\
5 \text { Alternative methods, techniques and courses of ac- } \\
\text { tion for special types of problems }\end{array}$ \\
\hline & \multirow{2}{*}{  } &  & $\begin{array}{l}6 \text { Understanding the incident, including the ability to } \\
\text { translate available information into scientific con- } \\
\text { cepts, to interpret and to draw conclusions } \\
7 \text { Application of general knowledge available to specific } \\
\text { problems in the incident } \\
8 \text { Analysis of complex incidents into well-defined sub- } \\
\text { problems and elements } \\
9 \text { Synthesis: Design of complex courses of action for } \\
\text { specific problems } \\
10 \text { Comparing and evaluating alternative courses of ac- } \\
\text { tion for specific problems }\end{array}$ \\
\hline & & 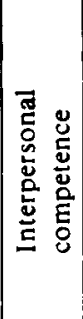 & $\begin{array}{l}11 \text { Openness towards feedback information in group } \\
\text { meetings } \\
12 \text { Ability to communicate and to cooperate with peo- } \\
\text { ple in the same discipline, other disciplines, and with } \\
\text { company experts } \\
13 \text { Ability for collective problem-solving and decision- } \\
\text { making in group meetings } \\
14 \text { Ability to lead individuals and task groups effectively }\end{array}$ \\
\hline &  & 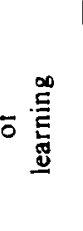 & $\begin{array}{l}15 \text { Problem consciousness and selective perception } \\
\text { towards the task } \\
16 \text { Readiness to respond in the face of challenging } \\
\text { problems } \\
17 \text { Motivation to achieve and cooperate in } \\
\text { problem-solving }\end{array}$ \\
\hline
\end{tabular}

very little help to the students in developing this ability. As problem-finding is an essential skill in management positions, it seems to be well justified to consider it as an important objective of the case method experiment. Similar arguments could be advanced in favour of the other 
specified objectives in the table. These objectives are based on the rather broad abilities that industry expects from university graduates, and are matched by traditional teaching methods in a very restricted sense only.

The objectives listed in the second part of Table 3, are classified, in rough outline, according to Bloom's wellknown taxonomy of cognitive and affective types of learning. ${ }^{9,10}$ Cognitive learning includes the acquisition of new, and the improvement of already existing knowledge, intellectual skills and abilities, while affective learning is more related to changes in motivational dispositions, attitudes and values. Each of the categories just mentioned includes hierarchically ordered sub-classes of learning objectives, indicating increasing complexity.

For the purpose of the case method experiment Bloom's taxonomy was modified in some respect. Apart from using more broadly-defined sub-classes of learning objectives, we did not restrict the category of skills and abilities to 'technical competence' only, as Bloom seems to suggest, but also extended it to 'interpersonal competence'. Some years ago Argyris investigated interpersonal competence thoroughly and stressed its importance for effective group problem-solving and decision-making. ${ }^{11,12,13}$ Therefore, an extended concept of skills and abilities is suggested in Table 3, though a sharp distinction between interpersonal competence and affective aspects of learning will not always be possible.

The taxonomy modified in this way turned out to be a very useful framework for defining in more detail the objectives of the case method experiment in terms of more knowledge, more technical competence, more interpersonal competence and, finally, in terms of an increase in desired attitudes, motivations and values. This framework helped a great deal, not only in the designing stage of the experiment, but even more in the subsequent executing stages, when various difficulties caused a tendency to lose sight of the overall intent of the experiment.

We pointed out in the introduction to this paper that more 'technical competence' and more 'interpersonal competence' were experienced as partially conflicting objectives in the course of the experiment. Nearly all participants had had so much exposure to teacher-centred courses, that during a rather long initial period, students tended to wait for detailed expert advice and instructions from university staff instead of deciding themselves what to do in the face of actual case incidents. On the other hand, university staff were, from tradition, only too ready to step in on group discussions, take over initiative, press for rational straightforward decision-making, minimize trial-and-error behaviour and look for results satisfying high scientific standards. From their point of view, student group meetings when largely left to student management seemed to be clearly less effective than traditional teacheroriented courses. However, the catalogue of objectives always reminded us that a somewhat slower growth rate of knowledge and technical competence might be the cost of realizing other equally valuable objectives like more interpersonal competence and improvements in the affective area of learning.

Until this point in the discussion, the objectives of the case method experiment listed in Table 3 have been con- sidered separately depending on whether they were defined in behavioural terms, as in the first part, or in terms of the taxonomy, as in the second part. Recent models of human behaviour point out that they are highly interrelated. In these models, cognitive factors like knowledge, skills and abilities on the one hand, and motivations on the other, are combined as main determinants of behaviour. ${ }^{14}$ From this kind of theoretical reasoning it becomes clear now that the behavioural objectives shown in the first part of the table are expected to be the results of learning in the cognitive and/or affective area. Thereby, it should be noticed that no attempt was made to specify the means-end-relationships for individual types of behaviour.

\section{Design of the case method experiment}

The case method experiment was designed as an instrument to accomplish the objectives listed above. In the present paper we confine ourselves to a short summary of the essentials which should help us to understand better what is measured later on in terms of cognitive and motivational effectiveness. ${ }^{1,2,3}$

Subject: Construction of a steam generator for a power plant.

Basic case material: Chronological survey of the project and its commercial and engineering execution, including a complete set of relevant documents, contracts and supplementary agreements.

\section{Selected partial projects:}

- Cost accounting and price determination for the steam generator in question;

- Self-construction of certain steam generator equipment or components vs. procurement from other firms;

- Financial problems connected with the execution of the order;

- Determining optimal dimensions for special steam generator equipment.

The first three projects were selected for treatment by the business students, the last one by the engineering students. As the basic case material provided routine solutions to the constructor for each of those types of problems, the standard question was what alternative courses of action were possible and how they were to be evaluated compared with the routine solutions observed.

\section{Conditions of participation for students:}

- Advanced students of the Business Institute at the University of Stuttgart with special interests in process technology;

- Advanced engineering students of the Institute for Process Technology at the same university with special interests in plant construction.

In contrast to traditional study programmes for the diploma in business administration (Diplomkaufmann), all students of the Business Institute in Stuttgart, in order to qualify for this diploma, have to pass final exams in process technology or in another engineering discipline, besides various economics subjects. Therefore, the conditions of participation just mentioned are not unreasonable. 


\section{Actual participants:}

- Two members of the Business Institute and one member of the Institute for Process Technology as instructors;

- Ten advanced students, among them five business and five engineering students, being regular participants and, in addition, a small and changing number of students as occasional participants;

- On the company side, a large firm engaged in the heavy machinery sector and some of its sub-contractors.

When the case method experiment was started in the winter term of $1977 / 78$, the study programme for the business degree was less than 3 years old. For this reason, and because of the strict conditions of participation, the number of potential participants was very small. Nearly all potential participants joined the experiment.

\section{Structure of activities:}

- Individual work of students;

- Team work in two disciplinary task groups of business and engineering students;

- Plenary meetings together with instructors;

- Joint meetings with top management and staff members of the cooperating companies in various forms, for example indoor and outdoor discussions, plant visits, etc.

A simplified model of the case method experiment indicating the structural elements and the communication channels between them might look like Figure 1 .

In the two-semester period of the experiment about 30 plenary meetings were held, most of them with only one of the task groups, but almost one-third as interdisciplinary meetings with both groups together. During the same period, six joint meetings with cooperating companies took place, covering one to two days each; special meetings of instructors with company members are not included. No attempt was made by instructors to record the attendence at the independent task group meetings and the time spent on individual work. Business students indicated that they had to spend an average of at least five hours per week on the case method experiment. Instructors said that they themselves had to invest, on the whole, two to three hours per week.

\section{Functional characteristics:}

- Plenary meetings dealt mainly with problem-finding and rough scheduling of successive problem-solving activities in task groups, defining information needs with regard to cooperating companies, discussing results of disciplinary group work, exchange of information and findings between the two groups, and preparation for joint meetings with company experts.

- Task group meetings covered functions such as detailed scheduling and executing of problem-solving activities according to fixed guidelines, defining additional information needs, allocating specific tasks to individual group members and discussing the results, and elaborating summaries and discussion papers for forthcoming plenary meetings.

- Individual work of each group member was primarily directed to perform separate tasks specified in the course of the group meetings.

- Instructors had as one of their most important functions to organize and to screen the continuous information flow between the learning system and the cooperating companies. Something more about their role in the case method experiment will be said in the context of the management approach used.

The information flow between the learning system and the cooperating companies turned out to be the crucial point in the case method experiment. Whenever one of the task groups tried to test alternative courses of action agains reality, their need for more and highly detailed information increased to an extent which could not always be satisfied completely by company members in the time available. These obstacles should be taken into account

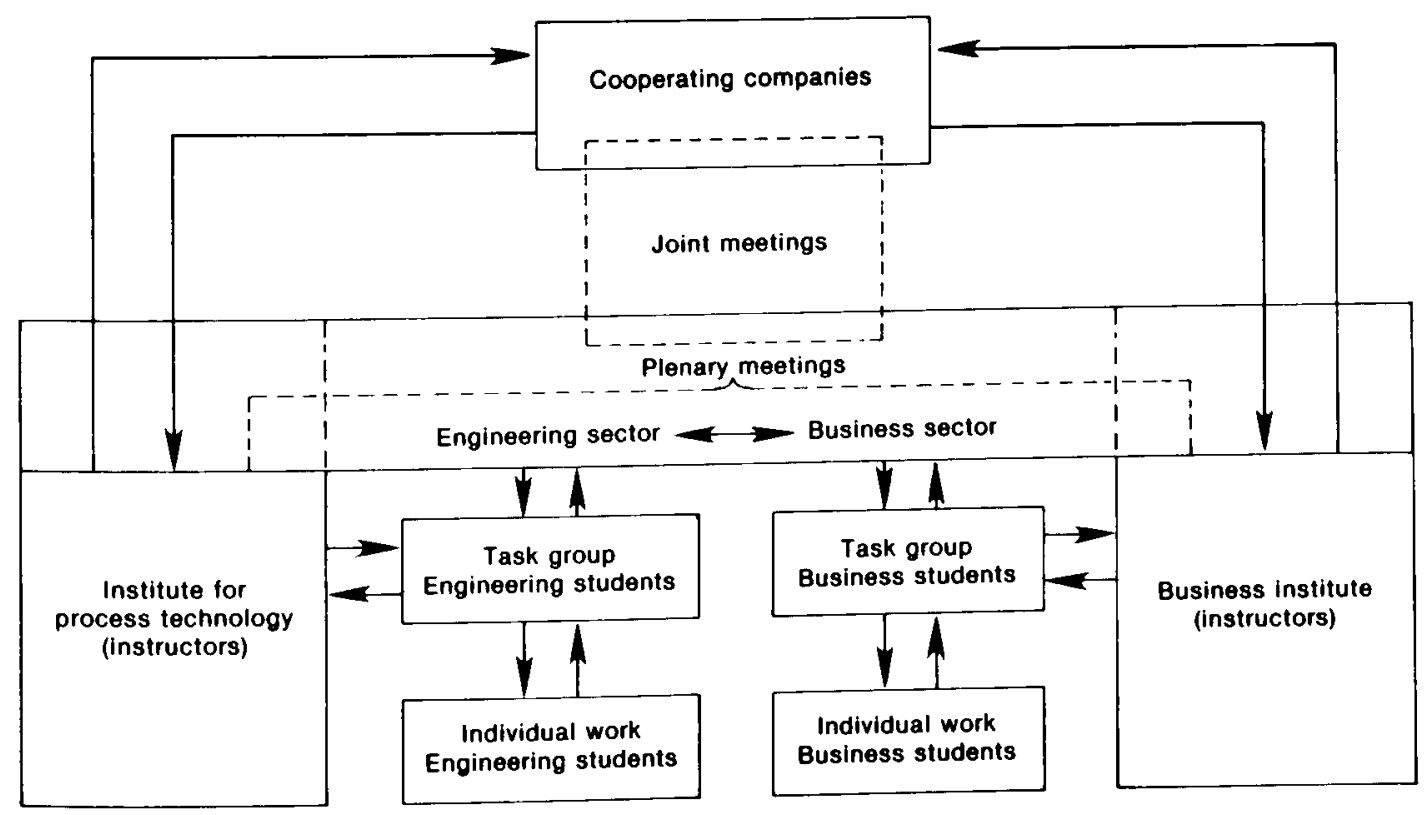

Figure 1 Simplified model of the case method experiment 
when the results of the completed problem-solving activities are evaluated against scientific quality standards.

\section{Management of group discussions:}

- All plenary meetings were guided by instructors. A 'moderator concept' was used as a compromise between 'laissez-faire' discussion and tight 'teachercentred' discussion, shifting as much activity, discretion and responsibility as possible to the student participants.

- Task group meetings were guided by changing student leaders elected by the group members. Within the framework fixed in rough outline by plenary meetings, participants in task groups could practice and experience full self-direction and self-control.

After having overcome large difficulties in the initial phase, it became increasingly easy in the course of ongoing learning processes of the students to realize the desired 'moderator concept' in plenary meetings and to delegate tasks with increasing complexity to the level of self-directive and self-controlling groups, as was intended according to the objectives defined for the case method experiment.

\section{Classification of the case method experiment}

In a survey of case method literature Perlitz and Vassen ${ }^{15}$ identified four basic types of cases: Case Problem Method, Incident Method, In Basket Exercises and, finally, Case Study Method. Trying to classify the case method experiment according to this scheme, we encounter difficulties. It is shown that the experiment includes components of different basic types. Obviously, the search for more information is a typical characteristic of the Incident Method, but some characteristics of the classical Case Study Method (and even of the Live Case Method as one of its more recent versions) are also involved. On the other hand, the various forms of immediate contact with business reality, which were a very important component of the case method experiment, are not adequately considered by the original classification scheme. Therefore, it is suggested that we distinguish an additional type of case method application which might be called 'Project Study Method' and will cover the case method experiment described in this paper as a special example. ${ }^{16}$

\section{Perceived effectiveness of the case method experi- ment from the students' point of view}

From the different methods for evaluating a training programme like the case method experiment, an ancnymous student questionnaire at the end of the experiment was selected. Though there are certainly more elaborate and objective evaluation approaches, ${ }^{15}$ we found that we had no real choice if we did not want to give up our system of objectives defined earlier. As far as the experiment was designed to encourage intrinsic instead of extrinsic motivation to work, and to develop interpersonal as well as technical competence and knowledge, any evaluation devices which required either some kind of performance test before and after the experiment or close observations during the ongoing project work were likely to be perceived as a contradiction and as a clear offence against the rules. Furthermore, a student questionnaire was expected to be in best accordance with the self-evaluation concept of the underlying Theory $\mathrm{Y}$ approach. The perceived effectiveness of the case method experiment was measured separately for cognitive and affective objectives discussed earlier.

\section{Perceived increases in knowledge and technical competence}

We have already mentioned that in the earlier stages of the experiment, the prevailing opinion claimed superiority for traditional teacher-centred courses when knowledge and technical competence were to be improved. However, this opinion was not confirmed by judgements of the participants, as is shown in Table 4.

Both groups, the business students and the engineering students, rated the case method experiment more effective than comparable university courses in regard to knowledge increase and developing technical competence. Although the business and engineering students evaluated the case method nearly the same in terms of mean item scores, they perceived its difference from traditional courses rather differently. Table 4 shows that the business students in the experiment evaluated traditional courses far less favourably than their engineering colleagues. The reasons are not quite clear. Whether those judgements reflect true quality differences in courses taught in the two disciplines considered, or whether they are due to personality differences between business and engineering students, cannot be decided on the data available. We suppose that another explanation is far more plausible. The intended concept of the case method experiment was realized almost in its pure form in the business group; however, for the engineering group some modifications in the direction of a traditional course were unavoidable, because they had to be acquainted with some business concepts. There was an objective reason, then, which might explain why the separate respondent groups perceived the superiority of the case method differently.

One should remember that a mixture of learning situations were used during the case method experiment. When each of those approaches were evaluated separately by the respondents, the following findings result.

The results shown in Table 5 lead to some interesting conclusions. Learning arrangements providing close and direct contact with cooperating companies were ranked highest in effectiveness. On such occasions, participants could experience immediate satisfaction of their information needs and obtain important help for their ongoing task group work. From this point of view the favourable aboveaverage evaluations for the first three items in Table 5 are understandable.

Among the other three learning situations, teamwork was evaluated as more effective than individual work on the project, although the latter was certainly an essential prerequisite for the first. Considering that students had considerable difficulties at the start of the case method experiment in handling problem-solving in autonomous task groups according to the principles of self-direction and selfcontrol, the result of their judgements at the end is surprisingly positive. Apart from the increase in knowledge and technical competence gained from the group situation, the perceived effectiveness also points to successful learning processes in the area of interpersonal competence and 
Table 4 Perceived increases in knowledge and technical competence according to 7-point-rating scales for case method experiment compared with traditional university courses

\begin{tabular}{|c|c|c|c|c|}
\hline \multirow[b]{2}{*}{$\begin{array}{l}\text { Knowledge and } \\
\text { technical competence }\end{array}$} & \multicolumn{4}{|c|}{$\begin{array}{l}\text { Perceived mean increases by means of ... } \\
\begin{array}{c}\text { Case method } \\
\text { experiment }\end{array} \quad \text { Traditional courses }\end{array}$} \\
\hline & $\begin{array}{l}\text { Business } \\
\text { group }\end{array}$ & $\begin{array}{l}\text { Engineering } \\
\text { group }\end{array}$ & $\begin{array}{l}\text { Business } \\
\text { group }\end{array}$ & $\begin{array}{l}\text { Engineering } \\
\text { group }\end{array}$ \\
\hline $\begin{array}{l}\text { Increase in knowledge } \\
\text { and problem-solving } \\
\text { ability }\end{array}$ & 5,7 & 6,0 & 4,3 & 5,5 \\
\hline $\begin{array}{l}\text { Increase in ability to } \\
\text { deal with real company } \\
\text { conditions }\end{array}$ & 5,7 & 5,5 & 1,7 & 3,5 \\
\hline $\begin{array}{l}\text { Increase in ability in } \\
\text { scheduling }\end{array}$ & 5,0 & 4,5 & 2,0 & 3,5 \\
\hline
\end{tabular}

Table 5 Perceived increases in knowledge and technical competence according to 7-point rating scales for different types of learning situations used in case method experiment

\begin{tabular}{|c|c|c|c|c|}
\hline \multirow{3}{*}{$\begin{array}{l}\text { Types of learning } \\
\text { situations used in } \\
\text { case method experiment }\end{array}$} & \multicolumn{4}{|c|}{$\begin{array}{l}\text { Mean increase in knowledge and technica } \\
\text { competence as perceived by . . }\end{array}$} \\
\hline & \multicolumn{2}{|c|}{ Business group } & \multicolumn{2}{|c|}{ Engineering group } \\
\hline & Rank & $\begin{array}{l}\text { Mean } \\
\text { scores }\end{array}$ & Rank & $\begin{array}{l}\text { Mean } \\
\text { scores }\end{array}$ \\
\hline $\begin{array}{l}\text { Seminars in cooperating } \\
\text { companies with top } \\
\text { management }\end{array}$ & 1 & 6,7 & 1 & 6,7 \\
\hline $\begin{array}{l}\text { Information visits to the } \\
\text { work-place and depart- } \\
\text { ments of the cooperating } \\
\text { companies }\end{array}$ & 2 & 6,0 & 3 & 5,3 \\
\hline $\begin{array}{l}\text { University seminars } \\
\text { with top management of } \\
\text { the cooperating compa- } \\
\text { nies }\end{array}$ & 3 & 5,7 & 2 & 6,5 \\
\hline $\begin{array}{l}\text { Working in largely } \\
\text { autonomous task groups }\end{array}$ & 4 & 5,3 & 4 & 5,3 \\
\hline $\begin{array}{l}\text { Individual working on } \\
\text { the project }\end{array}$ & 5 & 5,0 & 5 & 4,0 \\
\hline $\begin{array}{l}\text { Discussion in plenary } \\
\text { meetings }\end{array}$ & 6 & 4,0 & 6 & 3,0 \\
\hline
\end{tabular}

motivation - without these no such increase would have been possible. We shall have a closer look at the other criteria of effectiveness later.

From the students' point of view, 'discussion in plenary meetings' guided by university staff, was clearly the least effective of all the learning situations used in the case method experiment. This result needs some interpretation. First of all, it should be borne in mind that the functions of the 'plenary meetings' were quite different from those of task group sessions and other arrangements. Their accomplishment gave iess rise to perceptions of immediate increases in knowledge and technical competence. However, there is no doubt that the comparatively low effectiveness was also influenced by some specific problems associated with this type of learning arrangement. For ex- ample, deficiencies in cooperation between the business and the engineering groups, difficulties in obtaining needed information and, probably, initial problems in getting acquainted with the moderator approach followed in plenary meetings.

\section{Perceived increases in interpersonal competence}

The perceived effectiveness of the case method is even higher in the area of interpersonal competence, when compared with traditional courses.

The results shown in Table 6 were to be expected because traditional courses, which are not designed to improve interpersonal competence, are evaluated very low in effectiveness. Further, in these students' experience, business courses seem to be poorer in this respect than engineering courses. The higher ratings for the case method experiment are particularly impressive when the first two items in Table 6 are considered. These indicate strong increases in interpersonal competence related to team-work and to cooperation with company members.

There are sufficient reasons to believe that the respondents reacted very sensitively to different conditions. As was pointed out earlier, among the two groups considered, the business group had more and better opportunity to practice team-work according to our concept. This fact may explain why the business group experienced higher increases in their interpersonal competence for team-work than the engineering group. Another example is the relatively less favourable rating on the side of both groups when they had to evaluate the case method experiment with regard to perceived progress in cooperation with each other. Those judgements can be traced back to actual barriers we have mentioned.

On the whole, Table 6 leads to the conclusion that the case method experiment was perceived by the respondents as a very effective tool for increasing their interpersonal competence. If interpersonal competence is a prerequisite for experience, increasing knowledge and improving technical competence by means of team-work and cooperating with others, as Argyris ${ }^{11}$ has pointed out, then

Table 6 Perceived increases in interpersonal com. petence according to 7-point rating scales for case method experiment as compared with traditional university courses

\begin{tabular}{|c|c|c|c|c|}
\hline \multirow[b]{2}{*}{$\begin{array}{l}\text { Interpersonal } \\
\text { competence }\end{array}$} & \multicolumn{4}{|c|}{$\begin{array}{l}\text { Perceived mean increase by means of . . } \\
\begin{array}{l}\text { Case method } \\
\text { experiment }\end{array} \quad \text { Traditional courses }\end{array}$} \\
\hline & $\begin{array}{l}\text { Business } \\
\text { group }\end{array}$ & $\begin{array}{l}\text { Engineering } \\
\text { group }\end{array}$ & $\begin{array}{l}\text { Business } \\
\text { group }\end{array}$ & $\begin{array}{l}\text { Engineering } \\
\text { group }\end{array}$ \\
\hline $\begin{array}{l}\text { Increase in ability to } \\
\text { do team-work }\end{array}$ & 6,0 & 4,3 & 1,3 & 2,5 \\
\hline $\begin{array}{l}\text { Increase in ability to } \\
\text { cooperate with com- } \\
\text { pany managers and } \\
\text { experts }\end{array}$ & 5,7 & 5,5 & 1,7 & 3,5 \\
\hline $\begin{array}{l}\text { Increase in ability to } \\
\text { cooperate with en- } \\
\text { gineering students and } \\
\text { business students } \\
\text { respectively }\end{array}$ & 4,0 & 3,3 & 1,3 & 1,3 \\
\hline
\end{tabular}


this result may be regarded as the major finding of the case method experiment.

\section{Perceived effectiveness in the affective area}

The objectives defined for the case method experiment were not restricted to the cognitive area of human behaviour as represented by desired knowledge increases and improvements in technical and interpersonal competence. They also include the affective area. We tried to measure the perceived effectiveness in this area with two different kinds of question. In the first place, the respondents should primarily want to satisfy certain intrinsic motives closely related to the work itself instead of extrinsic motives related to forthcoming exams. Therefore, one of the questions asked the students to estimate the strength of those motives that had led them to the decision to join the case method experiment, while the second asked them to estimate the perceived satisfaction of the motives in question experienced by joining the experiment. For the purpose of comparison, the same questions were asked for traditional university courses. The results are shown in Table 7. According to Table 7 the case method experiment reached high effectiveness in regard to its affective objectives:

- As desired and expected in the beginning, intrinsic motives from the work itself and motives to cooperate were evoked by the case method much more than by comparable courses of the traditional type. One will also notice that 'importance for forthcoming exams' was almost no motive at all for joining the case method, but the dominating single motive for joining traditional courses. Regarding the latter, our worst apprehensions sometimes expressed in the critical statement that students study for nothing else than for passing the next exams, are confirmed. In a sense, this statement is a self-fulfilling prophecy, because believing in it prepares the ground for the strong tendency in the existing university education system to motivate students more or less exclusively by attaching exam relevance to each course and academic topic offered. This way of handling students' motivation problems has become so internalized that one can hardly imagine how any teaching arrangement, including applications of the case method, could work without strong references to the control system. Although the results of the case method experiment described here should not be generalized, they do show that there are motives beyond short-term exam pressure which can be voked by means of suitable arrangements.

- Table 7 points to a second aspect of effectiveness in the motivational area: Perceived satisfaction of evoked motives. The case method experiment was able to satisfy all relevant motives to join a course far better than comparable traditional courses, 'importance for exams' being the only exception.

We suppose that strength of motives evoked and satisfaction of motives are not completely independent. So far as growth needs are involved, high degrees of satisfaction as shown in the table generally agree with the perceived strength of the different motives. According to this mechanism the case method should be a useful tool to develop and to strengthen intrinsic motives and motives to cooperate within the existing university education system.

\section{Summary and perspectives}

Advanced undergraduates in the field of business administration and engineering at the University of Stuttgart were exposed to an interdisciplinary case method experiment offered for a two-semester period as a voluntary supplement to the existing standard study programmes. The perceived effectiveness of the case method applied was measured by means of an anonymous questionnaire covering different cognitive and motivational areas, and com-

Table 7 Perceived strength and satisfaction of motives according to 7-point rating scales for joining the case method experiment $(-)$ compared with traditional university courses (- - )




pared with that of lectures and other traditional teaching methods. The evaluations by participants indicate an impressive superiority of the case method with regard to increasing knowledge, and improving both technical and interpersonal competence. This is also true for the affective area of learning, including increased and better satisfied intrinsic motivation to achieve and to cooperate in small task groups. Our conclusion is that the case-method experiment was very successful in accomplishing the learning objectives which we had defined at the beginning, in contrast with some critical issues and deficiencies of the existing university education system.

However, we should be careful about generalizing the positive results of the case method experiment. There are, certainly, some weak points in the method of effectiveness measurement. Apart from the small sample size of respondents, measurement was restricted to ef fectiveness as perceived by the student participants, while no attempt was made to confirm these results in objective terms from the instructors' point of view. Another important reason why the findings are not to be generalized is that a very special type of case method was applied. It may best be described as an example of what is called 'project study method'. In the experiment, components of the classic case study and the incident methods were mixed together with various forms of immediate practice-relatedness, among them joint meetings with company managers and experts. Other even more specific characteristics come from the participation of cooperating groups of business and engineering students. In particular these specific characteristics arose from all the carefully designed arrangements which should have provided optimal learning situations, such as plenary sessions following an elaborate 'moderator concept', and largely autonomous group discussions under changing student leadership. What makes this experimental design so different from traditional teaching methods becomes clearer when described in terms of McGregor's management theory. In these terms the case method tends to be Theory Y-oriented, using guiding principles of management by self-direction and self-control. This relies on the predominance of intrinsic higher-order needs in human behaviour. The existing university education system is, on the contrary, generally more in line with Theory Xoriented management approaches.

This particular case method experiment cannot be repeated in exactly the same way, as is usually possible with other types of cases. Nevertheless, a rather general model is offered for future applications, showing how optimal use can be made of the high potential of the case method for practice-related improvements of university education.
To avoid misinterpretation we should stress the point that we used the case method strictly as a supplement to, but not as a substitute for, standard study programmes. In our opinion, which has been confirmed by the experiment, effective case method applications require that participating students already have broad theoretical knowledge and ability. From this point of view, theory-oriented lectures, courses and other traditional teaching arrangements have their own value for business education. The true problem to solve in the ongoing 'study reform discussion' about practice-relatedness is, therefore, not so much one of substituting traditional methods, but rather one of optimally integrating the case method in the existing university education system.

\section{References}

1. Ackermann, K.-F., Bohner, K. \& Rössle, W. Planung und Durchführung einer interdisziplinären praxisorientierten Projektstudie im Bereich des Grossanlagenbaus. Working Paper, Universität Stuttgart, 1978.

2. Ackermann, K.-F. Implementierung unmittelbarer Praxisbezüge im betriebswirtschaftlichen Studium. In Hron, A. et al. (Eds.), Praxisbezug im wirtschaftswissenschaftlichen Studium, Bd. 2, Materiatien und Erfahrungsberichte. Frankfurt 1979, pp. $165-178$

3. Bohner, K. Apparate optimal ausgelegt am Beispiel Luftvorwärmer. In Maschinenmarkt. Forschung und Konstruktion, Würzburg 86, 1980, Nr. 45, pp.881-884

4. Maslow, A.H. Motivation and Personality, 2nd. ed. New York, 1970.

5. Herzberg, F. et al. The Motivation to Work. 2nd. ed., New York, 1959.

6. McGregor, D. The Human Side of Enterprise. New York, 1960.

7. Ulrich, H. Zum Praxisbezug der Betriebswirlschaftslehre in Wissenschaftstheoretischer Sicht. Bern und Stuttgart, 1976.

8. Hron, A. et al. Praxisbezug im Wirtschaftswissenschaftlichen Siudium, Bd. I. Konzeptionelle Überlegung und Probleme der Umsetzung, Hamburg, 1979, pp.37-62.

9. Bloom, B.J. et al. Taxonomy of Educational Objectives. Classification of Educational Goals, Handbook I: Cognitive Domain. New York, 1956

10. Krathwohl, D.R., Bloom, B.S. \& Masia, B.B. Taxonomy of Educational Objectives. Classification of Educational Goals, Handbook II: Affecrive Domain. New York, 1964

11. Argyris, C. Interpersonal Competence and Organizational Effectiveness. Homewood, 1962

12. Argyris, C. Explorations in Interpersonal Competence. J. Appl. Behav. Sci., Vol.1, 1965, pp.58-83 and pp.255- 269.

13. Argyris, C. Interpersonal barriers to decision making. Harv Bus. Rev., Vol.XLVI, 1966, pp.84-97.

14. Porter, L.W. \& Steers, R.M. Motivation and work behavior. New York, 1975.

15. Perlitz, M. \& Vassen, P.J. Grundlagen der Fallstudiendidaktik. Köln, 1976.

16. Hron, A. et al. Praxisbezug im wirtschaftswissenschaftlichen Studium, Bd.2. Materialien und Erfahrungsberichte zu Formen des Praxisbezugs. Frankfurt, 1979. 